УДК [[008(477.8+438)"16":821.161.25(477)Гав7Тра]+32-051(438)Гер](045)

ORCID ID: 0000-0002-6215-9477

Гарбузюк Майя Володимирівна, доктор мистецтвознавства. Львівський національний університет імені Івана

Франка, Львів

Гарбузюк Майя Владимировна, доктор искусствоведения. Львовский национальный университет имени Ивана Франко, Львов

Maiia Harbuziuk, Doctor in History of Arts. Ivan Franko Lviv National University, Lviv

\title{
«ТРАГЕДІЯ, АБО ОБРАЗ СМЕРТІ...» Я. ГАВАТОВИЧА ЯК ДОКУМЕНТ ПОЛЬСЬКО-УКРАЇНСЬКОГО ТЕАТРАЛЬНОГО ПОГРАНИЧЧЯ: ПРИЧИНКИ ДО ІСТОРІЇ
}

Анотація. Статтю присвячено розширенню позатеатральних контекстів вистави «Трагедія, або Образ смерті пресвятого Івана Хрестителя...» Я. Гаватовича (1619). Уперше наголошено на можливому зв'язку поміж історією життя і громадської діяльності на захист русинів (українців) польського діяча Яна Щасного Гербурта (1567-1616), долею його Добромильської друкарні, фактом появи в ній двомовної «Трагедії...» Я. Гаватовича та сприянням цьому Регіни Жолкєвської з Гербуртів. Запропоновано гіпотезу про те, що друк «Трагедії..» міг бути способом символічного, прихованого вшанування пам'яті Яна Щасного Гербурта або ж, принаймні, став невід’ємною частиною польсько-українського культурного діалогу ранньомодерної доби.

Ключові слова: польсько-українське театральне пограниччя, Гербурти, Жолкєвські, Ян Щасний Гербурт, Добромильська друкарня.

Постановка проблеми та ї̈ актуальність. Запропонована стаття $є$ продовженням вивчення феномену українсько-польського театрального пограниччя, що був у центрі уваги недавньої міжнародної конференції «Україна-Польща: пограниччя театральних культур», проведеної у ЛНУ імені Івана Франка 12 грудня 2020 р. в рамках міжнародного проєкту «Театр CHOREA у діалозі 3 Україною» за участі провідних істориків театру з України та Польщі. Відправною точкою у цьому творчому та науковому діалозі послугувала «Трагедія, або Образ смерті пресвятого Івана Хрестителя, посланця Божого» Я. Гаватовича як перший відомий нам сьогодні документ польсько-українського театрального пограниччя. Пильна увага до цього твору та обставин, в яких він постав, привела авторку цих рядків до певних спостережень та гіпотез, які ще не були озвучені у науковому колі істориків театру і міркування над якими дасть можливість ширше окреслити місце, значення, специфічні особливості цього знакового твору.

Гіпотеза, запропонована у цій статті, базується на усвідомленні емблематичного характеру ранньобарокової культури, що дає змогу припускати наявність додаткових, прихованих сенсів, закладених у твір або ж в історію його появи/ друку. Ця гіпотеза базується також і на розумінні унікальності появи друкованого тексту не лише релігійної драми, а й українських інтермедій до нього включених. Адже йдеться про час, коли поява книги ніколи не була випадковою чи спонтанною, і кожен вихід у світ нового видання вже сам по собі містив певне повідомлення. Спробою відшукати ознаки такого прихованого повідомлення і викликана поява цієї статті.

Mema cmammi - окреслити позатеатральні контексти «Трагедії...» Я. Гаватовича, виявити зв'язки поміж окремими фактами, явищами, по- 
статями польсько-українського театрального та літературного пограниччя цього періоду; привернути увагу істориків українського та польського театру до маловідомих імен та творів польських авторів, які прагнули розвивати міжнаціональний, міжкультурний діалог.

Аналіз останніх досліджень і публікацій. Про ярмаркову релігійну драму «Трагедія, або Образ смерті...» та їі автора Я. Гаватовича писали окремо або ж згадували принагідно багато українських істориків театру та літератури (М. Драгоманов, П. Морозов, М. Павлик, Д. Антонович, М. Возняк, П. Житецький, В. Шевчук, І. Дзюба, О. Мишанич, М. Гудзій, Р. Пилипчук та ін.). Названі автори досліджували або згадували про подію у Кам'янці-Струмиловій 1619 з різних точок зору, зокрема, піднімали питання авторства інтермедій, європейської генези сюжетів та героїв, мови, лексики тощо. У працях театрознавців увага була сфокусована на вагомості двох інтермедій як початків історії українського театру нової доби. Увага літературознавців і мовознавців зосереджувалась на літературній та мовній специфіці цих інтермедій. Відомі історики видавничої справи в Україні (М. Запаско, Я. Ісаєвич, В. Овчинніков) згадували про факт друку «Трагедії...» у Яворові, в друкарні Яна Шеліги 1619 р. Однак напрацьовані дослідниками знання про цю подію у різних царинах гуманітаристики (історія театру, літературознавство, мовознавство, видавнича справа, краєзнавство, історія і т. д.) сьогодні існують відособлено, відтак поміж цими ділянками знань є лакуни, розриви, що викликають окрему увагу та потребу об’єднання довкола якогось спільного наративу. Чому саме цей текст зберігся для історії? Чому при друкуванні не були відкинуті українські інтермедіï? Чому він побачив світ саме у Яворові? Відповіді на ці та інші запитання кличуть до подальших спроб відчитати не лише видиму, легко зчитувану, а й затемнену часом, «потаємну» у чомусь історію.

Виклад основного матеріалу. На початку дослідження слід наголосити на потребі уважного ставлення не лише до історії написання та сценічного втілення релігійної драми Я. Гаватовича й українських інтермедій як їі складових, а й на історії, пов'язаній із друком повного тексту. Адже те, що сьогодні видається доконаним і логічним, насправді могло й не відбутися. Таких альтернативних варіантів могло бути як мінімум два: а) текст міг не бути видрукуваним узагалі і залишитися у найкращому разі коротко зафіксованим або згаданим принагідно фактом театраль- ного життя; б) його могли надрукувати без українських інтермедій, адже головною дидактичною частиною твору була біблійна історія. Тому є потреба придивитися уважніше до позатеатральних контекстів цих подій та, зокрема, змістити увагу 3 місця та факту показу вистави на місце й факт друку. Тоді важливими свідченнями і свідками стають для нас не лише текст драматичного твору й інтермедій, а й час і місце їх публікації, причетні до друку особи, доповнення, які виникли під час підготовки тексту до публікації.

Як відомо, текст «Трагедіі...» Я. Гаватовича був надрукований того ж 1619 р. «у Яворівським передмісті у св. Миколая» (Гаватович, 2006, c. 676$)^{1}$. I хоч ці дані було зазначено на титульній обкладинці видання, їх не одразу помітили чи коректно відчитали дослідники - принаймні, дуже ретельний М. Павлик у своїй розвідці назвав місцем друку Львів, а не Яворів (Павлик, 1900, c. 27), мабуть, уваживши Яворівське передмістя, зазначене на обкладинці видання, частиною Львова, а не вказівкою на м. Яворів (нині - райцентр Львівської обл.).

При підготовці до друку текст драми було доповнено трьома новими елементами: 3'явилося зображення герба, а також дві присвяти поетична та прозова. На центральній частині герба було зображене яблуко із трьома увіткнутими в нього ножами - родинний герб Гербуртів (Гаватович, 2006, с. 722). За зображенням ішла поетична присвята: «На чесний герб ясновельможної та милостивої пані, пані Регіни з Фульштина Жолкевської, канцелярини та гетьманової великої коронної» (Гаватович, 2006, с. 677). Оспівування цього герба Я. Гаватович розпочав такими рядками:

Не треба слів там, де річ сама править

На чесний герб глянь, все наочно ставить (Гаватович, 2006, с. 676).

У цій поетичній присвяті Я. Гаватович розкрив символіку герба так: три ножі - це слізна молитва, піст і благодійність ясновельможної пані Регіни Жолкєвської з Гербуртів. Три ножі - на думку поета — це ще й три одвічні християнські чесноти: Віра, Надія, Любов. Яблуко ж потрактовано як знак Божої безмежності, в якій вони перебувають:

Мечів три будьте у яблуко вбити

Оте безмежне візьми, зумій вжити (Гаватович, 2006, с. 677).

\footnotetext{
1 Тут і далі цитати подаємо у перекладі В. Шевчука (Гаватович, 2006).
} 
Важливо звернути увагу на перший меч «молитву сльозисту / що пані чесна зливає, щедристу» (Гаватович, 2006, с. 678). Пишучи так у 1619 р., Я. Гаватович ще не міг знати про те, що вже за кілька років Р. Жолкєвська оплакуватиме спершу чоловіка Станіслава, який загине у битві під Цецорою 1621 р., а невдовзі по тому - сина Яна. По кому ж тоді був плач шляхетної Регіни 1619 р., про який рядком згадав поет? Чи дозволено нам здогадатись про це?

За поетичною присвятою йшла об'ємна прозова, в якій драматург пояснював причини своїх театральних аспірацій бажанням «розмножувати та розширювати ту Хвалу Господню в діточках, мені доручених», а також створити виставу «на оздобу» славетного містечка Кам'янки (Струмилової - М. Г.), що належало Жолкєвським, та задля виказу «ладу усілякого в нім» (Гаватович, 2006 , с. 678). Далі драматург наголошує - і у перекладі В. Шевчука читаємо саме так - про бажання автора, аби його патронеса могла насолодитись і виставою, і видрукуваним текстом:

Ота маленька праця моя, щоб абияк не відбулася, під опіку та оборону В[ашої] М[илості], моєї милостивої пані і добродійки, пустивши, зичу того навзаєм, аби В[аша] М[илість], моя милостива пані, не лише 3 вистави, а від читання була втішена. (Гаватович, 2006, с. 678)

Такий варіант перекладу саме цього моменту присвяти дає змогу по-іншому поглянути на мотивацію видання. Ще від М. Павлика ці рядки були потрактовані як свідчення того, що Р. Жолкєвська iз невідомих причин на виставі не була — а отже головною причиною друку п'єси слугувало саме бажання забезпечити їй читання п'єси (Павлик, 1900 , с. 27). Одначе той самий вислів у польському тексті можна прочитати і так, як це зробив перекладач В. Шевчук, тим більше, що у цій же присвяті Я. Гаватович засвідчує присутність на виставі і самого гетьмана коронного та старости Кам'янецького Станіслава Жолкєвського, чоловіка Регіни. Отже, якщо прийняти цю версію, то друк видання міг не компенсувати відсутність Регіни на виставі, а, навпаки, - подвоювати цінність побаченої нею вистави додатковою «опцією» друку. Якщо зважити на це, тоді публікація «Трагедії...» з українськими інтермедіями справді засвідчувала унікальність, важливість твору для найближчого до автора кола сучасників.

Саме тому додані у виданні нові елементи привертають до себе окрему увагу. Не складно помітити, що поруч із зображенням родинного герба Гербуртів саме прізвище Гербуртів жодного разу не прозвучало у присвятах. Я. Гаватович двічі називає Регіну як «Регіну з Фульштина Жолкєвську" (йдеться про родинне гніздо Гербуртів - село Фульштин/Фельштин, нині - с. Скелівка Старосамбірського р-ну Львівської обл.). Присутність Гербуртів позначена символічно, гербом, але не проявлена вербально. Чому?

Сама посвята на перший погляд — типова для свого часу ознака ввічливості, одне з численних свідчень розвиненої клієнтелли у ранньомодерній Речі Посполитій. «Річ Посполиту я вважаю за особливо виразний приклад функціонування клієнтарних зв'язків», - пише, зокрема, сучасний польський історик А. Мончак $(2020$, с. 262). Ідеться про взаємини поміж патроном і потребуючим його опікунства «клієнтом», без чого складно було сформувати свою життєву траєкторію будь-якому представникові шляхти, особливо із незаможних родин. Ці взаємини діяли на різних рівнях - Я. Гаватович у різний час мав за своїх патронів родини Сенявських та Жолкєвських, а сам Станіслав Жолкєвський свого часу підлягав патронату Яна Замойського, однієї з найвпливовіших осіб у Речі Посполитій другої половини XVI-початку XVII ст. Сьогодні важко зрозуміти, з яких саме причин у друкованому виданні із присвятою Регіні Жолкєвській та виданим, очевидно, iii коштом, стоїть герб Гербуртів, а не Жолкєвських?

Отже, маємо щонайменше три запитання: кого у «слізній молитві» оплакувала Регіна Жолкєвська? Чому поруч із гербом Гербуртів їхне прізвище жодного разу не було назване? Чому, врешті, акцентовано саме герб Гербуртів, якщо Кам'янка-Струмилова, де вчителював Я. Гаватович і де відбулась вистава, як і Яворів, де було видрукувано згодом книжку 1619 р., перебували у володіннях Жолкєвських?

Якщо у пошуку відповідей на ці питання уважніше придивимося до історії тієї друкарні у м. Яворові, звідки вийшла у світ «Трагедія...» Я. Гаватовича 1619 р., то й тут побачимо... слід Гербуртів, зокрема одного із них - Яна Щасного Гербурта (1567-1616). Але спершу з'ясуємо важливу інформацію про сам цей рід.

Гербурти - одна з найвідоміших в Галичині шляхетських родин. Їхні предки знані на галицьких землях з середини XIII ст., куди вони переселилися $з$ німецьких територій. Родинною оселею Гербуртів було село Фельштин/Фульштин, звідки й походила Регіна Жолкєвська (до заміжжя - Гербурт). Гербурти упродовж XIII-XVI століть були відомими діячами у політичному та суспільному 
житті краю. Як зазначає історик-краєзнавець Ігор Мельник,

$<\ldots . .>$ XV-XVI ст. представники роду Гербуртів породичалися зі шляхетними родами Руського воєводства, займали важливі державні посади, навчалися в європейських університетах, поширили свої маєтності на Поділля, де заснували ще один Фельштин (тепер село Гвардійське у Хмельницькій області). (Мельник, 2016)

Знаний польський журналіст і краєзнавець Владислав Лозинський на початку XX ст., характеризуючи Перемиську землю у складі Речі Посполитої (до якої належали й володіння Гербуртів), написав так:

Панівна над воєводством та найстарша в ньому є культура, найгустіше закладена, найчисленніша, найбагатша < ..> Вона насамперед і поєднує усе воєводство зі світом, з Річчю Посполитою, із Західною культурою, з рухом умів у Європі <..> Тут найбільше науки, найбільше талантів, і найбільше політичної опозиції, тут гніздо Гербуртів і Оріховських. (Лозинський, 1904, с. 148)

Саме С. Оріховському-Роксолану, відомому ренесансному мислителю та письменнику, який незмінно ідентифікував себе як Русин (Роксолан), належала оцінка роду Гербуртів, з якими Оріховські сусідили: «Ніколи не помилишся у жодному з Гербуртів, бо у нього за рідного брата - людина, яка правду, віру, справедливість і мир любить» (Цит. за Соколовський, 1883, с. 336). Історик А. Соколовський подав ще один вислів, нібито поширений серед польської шляхти XVI ст.: «На скільки Острозькі фортуною (тут ідеться про фінансовий успіх. - М. Г.), на стільки Гербурти розумом і мудрою порадою знані в Речі Посполитій» (Соколовський, 1883, с. 337).

Найвідомішим з Гербуртів зламу XVI-XVII ст. був Ян Щасний Гербурт з Добромиля (15671616). Його батько, Ян Гербурт (після 1524-1577), відомий польський шляхтич, гуманіст, історик, письменник, дипломат, громадський діяч, правник, також походив із Фельштина. А отже, поміж Регіною з Фельштина Жолкєвською та сином Яна Гербурта — Яном Щасним Гербуртом - існували родинні стосунки. Забігаючи наперед, скажемо, що це саме йому належала та друкарня, що по його смерті 1616 р. разом із друкарем Яном Шелігою перемістилася 3 Добромиля до Львова, а звідтіль на короткий період 1618-1619 рр. — до Яворова. Саме зі стін цієї друкарні вийшла у світ 1619 р. «Трагедія...» Я. Гаватовича. Отож є потреба детальніше познайомитися із постаттю самого Я. Щ. Гербурта.
Ім’я Яна Щасного Гербурта (Jan Szęsny Herburt) $з$ Добромиля сьогодні не можна назвати забутим чи невідомим. Інформація про нього наявна у працях істориків, літературознавців, а також у художній літературі. Короткі відомості про нього містять енциклопедичні гасла Малої української енциклопедії (Онацький, 1967, с. 2100) та Енциклопедії історії України (Дзюба, 2004, c. 90), а також Польського Біографічного Словника (Cynarski, 1960-1961, s. 443-445). У XIX ст. - на початку XX ст. про нього писали польські журналісти та краєзнавці А. Соколовський (Sokolowski, 1883) та В. Лозинський (Lozinski, 1904). Окремий розділ «Гербурт в обороні руської справи» присвятили йому автори- упорядники польського видання «З історії України» (Z dziejow Ukrainy, 1912), присвяченого пам'яті видатних українських діячів польського походження: Володимирові Антоновичу, Павлину Свєнціцькому, Тадею Рильському. Одним з перших українських дослідників його згадує український історик В'ячеслав Липинський у своїй книжці «Україна на переломі 1657-1659» (Липинський, 1954. с. 241242). Не забуває про нього у своїй монографії «Історія Речі Посполитої як історія багатьох народів, 1505-1795. Громадяни, їхня держава, суспільство, культура» один з відомих сучасних польських істориків Анджей Сулима Камінський (Камінський, 2011 , с. 96). Окрему монографію присвятив цьому діячеві сучасний історик з міста Санок Я. Серафін (Serafin, 2017).

Згадки про Я. Щ. Гербурта знаходимо і в працях театрознавців (Пилипчук, 2019), (Гарбузюк, 2018), і в літературознавчих розвідках (Шевчук, 2008), і в істориків книговидавничої справи в Україні (Запаско, Ісаєвич, Овчинніков).

Проте чи не найбільшу увагу до постаті Яна Щасного Гербурта привернула сучасна українська письменниця і землячка Гербуртів Галина Пагутяк. Її перу належать роман «Слуга з Добромиля» (Пагутяк, 2006), відзначений 2010 р. Національною премією України ім. Т. Шевченка та роман «Магнат» (Пагутяк, 2014), а також низка публіцистичних статей на тему життєвої та творчої долі Я. Щ. Гербурта (Пагутяк, 2011; 2013). Серед інших журналістських публікацій слід згадати допис Є. Гулюка (Гулюк, 2017). Згадані тексти у різних жанрах присвячені осмисленню місця та значення для української культури літературного, духовного, матеріального внеску Я. Щ. Гербурта та його сім'ї. Йдеться про розквіт Добромиля та прилеглих сіл, що припав на перші десятиліття XVII ст., коли Я. Щ. Гербурт створив тут Добро- 
мильський культурний осередок, знаний далеко за межами Руського воєводства.

Отже, на підставі інформації із зазначених вище джерел коротко окреслимо життєвий шлях Я. Щ. Гербурта. Він народився 25 січня 1567 року у родинному маєтку Боневичі біля Добромиля (нині - села Львівської обл.), а помер 31 грудня 1616 р. у власному маєтку в Добромилі. По смерті батька, у віці дванадцяти років Я. Щ. Гербурт потрапив під опіку Яна Замойського, коронного канцлера Речі Посполитої, надзвичайно впливової людини. Опікун забезпечив вихованцеві блискучу європейську освіту (навчався в університетах Кракова, Інгольштадта, Парижа) та вплив вільнодумних республіканських ідей, які сам сповідував. Розпочата у двадцять років блискуча дипломатична кар'єра обіцяла одному 3 найосвіченіших юнаків яскраве майбутнє. Він брав участь у низці важливих для польського короля перемов і домовленостей, зокрема, у статусі королівського секретаря. Понад десять років присвятив Я. Щ. Гербурт цій діяльності, якнайкраще проявивши свої здібності та освіту. Сучасний український історик М. Кріль зазначає:

Цей високоосвічений магнат кілька років провів на дипломатичній службі, побував із посольством в Англії (1588), в Римі (1589), в Австрії (1590), у Криму (1595), в Московії (1595), у Туреччині (1598-1599). У складі польського війська брав участь у війні з Волоським князівством та у придушенні козацько-селянського повстання під проводом Северина Наливайка. Тривалий час обирався послом сейму $(1587,1590,1596,1604$, 1615). (Кріль, 2014)

Під час численних закордонних вояжів Свропою у складі найвищого почту та дипломатичних місій чи міг він бачити театральні вистави? Про це не йдеться в жодному документі, але слід припустити таку можливість із великою ймовірністю. Адже європейський театр того часу був розвагою для еліти, до якої належав і Я. Щ. Гербурт. Нагадаймо, що був він сучасником В. Шекспіра та Лопе де Веги. А також він був добрим музикантом, про що свідчить портрет у костелі Бернардинів у Львові (нині - Церква св. Андрія), де Я. Щ. Гербурта зображено із музичним інструментом у руках (Цебенко, 2018).

При всіх можливостях, які надавала молодому інтелектуалові придворна дипломатична кар'єpa, Я. Щ. Гербурт не гнався за особистим успіхом чи матеріальним збагаченням. І це було родинною традицією, як акцентують дослідники:

Якщо інші роди за криваві послуги Речі Посполитій, за спритні і корисні поради, часом до догоджання королівським фантазіям, багатіли на староства і скжетною господаркою примножували свої маєтки, то Гербурти шукали на полі битви героїчної загибелі, а в час миру віддавалися більше наукам ніж володарюванню і спекуляції, хоча теж були амбітні та горді; слава значила для них добре ім'я, вони зневажали <...> посади і достаток. (Соколовський, 1883, с. 337)

На зламі XVI-XVII ст. залучив Я. Замойський свого вихованця до формування і відкриття Замойської академії - третього у Речі Посполитій після Ягеллонського та Вільнюського університетів навчального закладу такого рівня і першого - приватного (Дзюба, 2004). Важливо наголосити, що навчання у Замойській академії було зорієнтовано і на слухачів зі східних земель Речі Посполитої. Серед іiі випускників було багато руської талановитої молоді - зокрема, майбутній ректор Києво-Могилянської академії Касіян Сакович, знаний політик Адам Кисіль та ін. Серед організаторів і викладачів Академії був також один 3 найвідоміших тогочасних поетів - Шимон Шимонович. Це йому належить впровадження нового для польської літератури жанру «селянки», тобто поезії на ідилічно-селянську тематику з виразними елементами реалізму. Показово, що сама назва жанру походила від руського слова «село» і свідчила про взаємне проникнення лексики та мовних зворотів двох мов. Серед найвідоміших «селянок» Ш. Шимоновича - «Жнива», де автор звернувся до русинської теми. Знайомство Я. Щ. Гербурта із Ш. Шимоновичем не підлягає сумніву, адже обидва вони пов' язані із початками діяльності Замойської академії.

Одружившись 1601 р., Я. Щ. Гербурт осів у своєму родинному маєтку в Добромилі. Його дружина, Ельжбета Заславська з Острозьких, походила зі славетного княжого руського роду. Вона в усьому підтримувала чоловікові зацікавлення та ідеї, цілком ймовірно, що завдяки і ії впливу Я. Щ. Гербурт прийшов до свідомого захисту прав русинського люду. Принаймні в одному 3 пізніших текстів Я. Щ. Гербурт, стаючи в обороні «шановного русинського народу» скаже, що 3 нього «я і дружина моя взяли свою кров» (Цит. за Соколовський, 1883 , с. 89). Подружжя подарувало місту землю для спорудження монастиря (саме в цьому монастирі свого часу розпочав своє молитовне служіння майбутній митрополит Андрей Шептицький).

Критичне ставлення до політики польського короля привели Я. Щ. Гербурта у ряди рокошу Зебжидовського - збройного повстання, скерованого 
проти Зигмунта III Вази (1606-1609). Після розгрому рокошан Я. Щ. Гербурта як одного з керівників повстання було заарештовано у селі Тайкур поблизу м. Острог, засуджено до страти, яку було замінено на ув'язнення. Він відбув 20 місяців у в'язниці у Кракові (Galuszka, 2017). Саме на цей період припадає його активна літературна діяльність.

Тут, в ув'язненні пише він свою алегоричну автобіографію, справжній зміст якої до сьогодні не розшифрований дослідниками. Твір, який мав первісну назву «Гадка Гриця з Фортуною» (і назва ця засвідчувала самоідентифікацію автора із персонажем-русином), був побудований як діалог, в якому герой полемізував із Фортуною та Цнотою, де перша прагнула звести його $з$ правильного шляху, а друга - втримати. Саме у цьому діалозі знайшла місце пісня українською мовою, написана вочевидь самим Я. Щ. Гербуртом. Записана латинською абеткою, вона демонструвала вільне володіння поетом мовою русинів, серед яких він жив, а головне - промовляла до руського народу словами любові та навіть ніжності. Письменниця Г. Пагутяк, яка першою увела в публічний український простір цей текст, наголосила, що лексика пісні відображає бойківський діалект, типовий для місцевості, де мешкали Гербурти. Оскільки цей вірш практично невідомий українському театрознавству і важливий у світлі нашої теми, вважаємо за потрібне подати його у тому варіанті, як його подала Г. Пагутяк:

Pastusze, pastusze, / Пастуше, пастуше,

Liubliu te do dusze, / Люблю тя то душі

A szczo mene boli, / А що мене болі

Skazu ty do woli / Скажу ти до волі.

Czerodyku majesz, / Черодийку маєш,

Riadit jej ne znajesz. / Рядить їй не знаєш

Tobi z neiu licho, / Тобі з нею лихо,

Jej z tobu nie tycho. / Їй з тобов не тихо

Bywal to didojko / Бивав то дідойко

Mil sia choroszejko. / Мав ся хорошойко

Wolki sia bojaly / Вовки ся бояли

Czeredu mijaly. / Череду минали.

Da szczoz nam czynyty! /Та що ж нам чинити!

Terpity, terpity. / Терпіти, терпіти.

Z Bohem sia ne byty. / 3 Богом ся не бити. (Пагутяк, 2013)

Після звільнення із в'язниці 1609 р. Я. Щ. Гербурт мав зобов'язання не полишати свого маєтку та не брати участі у суспільно-громадському житті країни, тож зосередив свою енергію на видавничій справі. У 1611 році він запросив з Кракова відомого друкаря Яна Шелігу із його приватною друкарнею і заснував у с. Боневичі друкарський осередок, перетворивши Добромиль на культурний центр (Ісаєвич, 2013).

Видавнича програма Я. Щ. Гербурта була продовженням опозиційної діяльності щодо політики короля. Так, саме у цій невеликій друкарні уперше побачили світ історичні праці: «Хроніки» Яна Длугоша, «Аннали» С. Оріховського, твори Вінцента Кадлубка (Дзюба, 2004). У такий спосіб Я. Щ Гербурт прагнув дати співвітчизникам їхню історію, розвивати просвіту. Усього за 5 років було видано тринадцять книг польською та латинською мовами, деякі із них (наприклад, «Історія Польщі» Я. Длугоша) — накладом у півтори тисячі примірників.

У своїй друкарні Я. Щ. Гербурт видавав i власні тексти, в яких викладав критичні погляди на політику короля, зокрема, й щодо насильницького поширення унії на руських землях. Найвідомішим із них $\epsilon$ «Розмисел про народ руський, написаний під час московської конфедерації (1613) паном Щасним Гербуртом Добромильським, старостою Вишницьким та Мостицьким» (Гербурт, 2008). Цей полемічний за характером текст мав відверто проукраїнську (прорусинську) позицію:

Таке й оце колотнеча, яку почали з народом руським, братами й кревними нашими, вона ніби рана в серце, котра, хоч би й найменша була, приносить смерть.

Одну частину справи розумію, а другу частину, хоч про неї постійно мислю, утямити не можу.

Бо знаю добре про те, що з ними діється, почавши від Брестського з'їзду. Знаю добре, як на сеймиках подають їм надію, а на сеймах із них сміхи ладнають . На сеймиках обіцяють, а на сеймах шикають. На сеймиках братами називають, а на сеймах - відщепенцями. Це я знаю, бо все це правда. Але чого вони хочуть од того шляхетного народу, якою радою і якою метою вони керуються? Того я в жодний спосіб збагнути не можу. Бо коли хочуть, щоб Русі не було в Русі, то це річ неподобна, і це все одно, якщо порівняти, якби їм захотілося, аби море було поблизу Самбора, а Бершадь неподалік Гданська. (Гербурт, 2008, с. 465-466)

Текст цей був видрукуваний у Добромильській друкарні 1613 р. Ще один, автором якого зазначено Войцеха Кіцького, «Діалог про оборону України та побудка з пересторогою», був виданий 1615 р. у тому ж Добромилі (Kicki, 1615). У цьому творі була виведена Україна як окремий персонаж, що у діалозі зі своїм оборонцем - вояком, жалілася на татарські набіги та беззахисність перед ними (Кіцький, 2006). Навряд чи цей твір, 
написаний у діалогічній формі, було створено для сцени, але декламувати «в особах» його могли у колі Я. Щ. Гербурта або ж учні однієї із довколишніх шкіл, наприклад, того ж Фельштина.

Врешті видавнича діяльність та політичні погляди Я. Щ. Гербурта викликали сильне незадоволення і місцевої шляхти, і прихильників королівської влади. Друкарню була позбавлено королівського дозволу. Обрання Я. Щ. Гербурта 1616 р. послом на сейм було відмінено через «неблагонадійність». Наклад «Хронік» Я. Длугоша також потрапив під заборону. На самого Я. Щ. Гербурта очікував суд. Від цього ганебного та принизливого процесу його врятувала раптова смерть 31 грудня 1616 р. У віці 49 років Я. Щ. Гербурт, католик, що обстоював права руського люду та православної церкви, відійшов у вічність.

По смерті власника Добромильських маєтностей, вже наступного року, друкар Ян Шеліга із друкарнею переїхав до Львова, а у 1618 1619 pp. - до Яворова, де працював при монастирі домініканів у церкві св. Миколая. Старостою яворівським на той час був молодий Ян Жолкєвський - син тих самих Жолкєвських, Станіслава й Регіни з Гербуртів, про яких вже йшлося на початку дослідження. Тож, без сумніву, у справу допомоги опальній приватній друкарні включились родинні зв'язки Гербуртів-Жолкєвських.

Насправді поміж цими двома родинами приязні стосунки були тривалими та взаємними: Станіслав та Ян Щасний були разом у військових походах, вони мали одного патрона в особі Яна Замойського, і навіть під час рокошу Зебжидовського, коли доля розвела їх по різні боки барикад, це значною мірою визначило результат протистояння (Galuszka, 2017, s. 6). Сьогодні істориків дивує факт втечі Я. Щ. Гербурта з поля бою під Гузовом, коли навпроти його тисячного війська постало військо Станіслава Жолкєвського (Galuszka, 2017, s. 8). Але саме цей факт якнайпереконливіше свідчить, що Я. Щ. Гербурт обрав поразку і полон але не битву зі С. Жолкєвським.

Чи варто сумніватись, що для обох Жолкєвських - i Станіслава, і Регіни з Гербуртів смерть Я. Щ. Гербурта була відчутною утратою? Станіслава Жолкєвського та Яна Щасного Гербурта, зокрема, пов'язували роки спільних військових походів, патронат коронного гетьмана Яна Замойського (котрий мав за жінку Анну з Гербуртів). Тож чи тільки через захоплення виставою Я. Гаватовича постановила Р. Жолкєвська видрукувати їі повний текст та взяла на себе витрати? Чи могла вона в історії невизнання, наруги та страти біблій- ного героя побачити певну аналогію 3 життєвим шляхом свого родича? Сьогодні знаємо надто мало, аби стверджувати напевне. Цікаві відповіді може дати ретельний текстуальний аналіз драми. А раптом в ній звучать притаманні Я. Щ. Гербурту інтонації, думки, вислови, яких ми ще не чуємо?

Тим часом на підставі викладеної інформації та відповідаючи на поставлені на початку питання, можемо зробити наступні обережні висновки

\section{та припущення.}

Перше. Ймовірно, не випадково згадана у поетичній присвяті «слізна молитва» Регіни Жолкєвської могла стосуватись оплакування раптової смерті найвидатнішого з Гербуртів, до родинного древа яких вона належала.

Друге. Замовчування імені славетного роду Гербуртів у присвятах до «Трагедії...» - поруч із надрукованим родинним гербом - могло свідчити про ще свіжу заборону або ж принаймні небажаність згадки цього імені у публічному просторі.

Третє. Підкреслене акцентування чеснот та слави Гербуртового герба у присвятах могло мати більш ніж символічне значення, а все видання, формально присвячене Регіні з Гербуртів, відтак могло слугувати засобом увічнення пам'яті Яна Щасного Гербурта. Адже друкований твір, в якому поруч із польською частиною містились тексти українських інтермедій, мав бути найкращим пам'ятником людині, що боролася за рівність i права русинів у Речі Посполитій.

Запропонована гіпотеза потребує подальшого, зокрема, й детального текстологічного, дослідження. Але здійснена уперше спроба пов'язати розрізнені досі факти й події з історії родини Гербуртів та «Трагедією...» Я. Гаватовича дала можливість принаймні на цьому етапі розкрити ширші соціокультурні контексти феномену польсько-українського пограниччя початку XVII ст. та артикулювати невипадковість появи цього твору та його видання 1619 р. у Яворові в друкарні Яна Шеліги.

\section{Бібліографія}

Антонович, Д. (1925) Триста років українського театру 1619-1919. Прага: Український громадський видавничий фонд. $276 \mathrm{c}$.

Возняк, М. (1919). Початки украӥнської комедї (1619-1919), Львів: Видання «Всесвітньої бібліотеки». 252 с.

Гаватович, Я. (2006). Трагедія, або Образ смерті пресвятого Івана Хрестителя, посланця Божого (перекл. В. Шевчука). В Слово многоцінне: в 4-х т., Т. 1, Київ: Аконіт. C. 676-722.

Гарбузюк, М. (2018). Образ України у польському театральному дискурсі XIX ст.: стратегії та форми репрезентації. Львів: Простір-М. 470 с. 
Гулюк, Є. (2017). Обережно з історією, або «Друкарські війни» під Львовом. Відновлено 3: https://photo-lviv.in.ua/ oberezhno-z-istorijeyu-abo-drukarski-vijny-pid-lvovom/

Дзюба, О. М. (2004). Гербурт Ян-Щасний. В Енциклопедія історії України : в 10 т. ; В. А. Смолій (голова) та ін. Т 2: Г-Д. Київ: Наукова Думка. С. 90.

Дмитрова, Л. (1929). Підручна книга з історії всесвітнього театру. (Вступ та ред. О. Білецький). Вип. 1. Київ: Державне видавництво України. $472 \mathrm{c}$.

Запаско Я., Ісаєвич Я. (1981). Пам'ятки книжкового мистецтва: Каталог стародруків, виданих на Україні. Кн. 1. Львів: Вища школа. С. 37-38.

Ісаєвич, Я. (2002). Украӥнське книговидання: витоки, розвиток, проблеми. Львів: Інститут українознавства ім. I. Крип'якевича НАН України. 520 с.

Ісаєвич, Я. Д. (2013). Шеліга Ян. В Енцииклопедія історї Украӥни. В. А. Смолій (голова) та ін. Т. 10: Т-Я. Київ: Наукова думка. Відновлено 3: http://www.history.org. ua/?termin=Sheliha_Y.

Камінський, А.С. (2011). Історія Речі Посполитої як історія багатьох народів, 1505-1795. Громадяни, їхня держава, суспільство, культура. Перекл. 3 пол. Київ: Наш час. 263 c.

Кіцький, В. (2006). Діалог про оборону України... Пер. $з$ пол. В. Шевчук. В Слово многоиінне: хрестоматія українськоі літератури, створеної різними мовами в епоху Ренесанcу (друга половина $X V$-XVI століття) та в епоху Бароко (кінець XVI-XVIII століть): в 4 кн. Кн.1. Київ: Аконіт. C. $602-620$.

Кріль, М. (2014). Низький замок. Пам'ятки Украӥни: історія та культура. № 3. С. 20-27.

Липинський, В. (1954). Украӥна на переломі 1657-1659 : замітки до історії українського державного будівництва в XVII-ім століттю. Вид. 2-ге. Нью-Йорк: Булава. 304 с. C. 241-242.

Мельник, І. (2016). Ян Щасний Гербурт з Добромиля. Відновлено 3: https://zbruc.eu/node/60617

Мончак, А. (2020). Нерівна приязнь. Клієнтарні взаємини в історичній перспективі. Київ: Темпора. 768 с.

Онацький, Є. (1967). Українська мала енциклопедія. Кн. XVI. Літери УШ-Я. Буенос-Айрес: адміністратура УАПЦеркви. $176 \mathrm{c}$.

Овчинніков, В. (2005). Історія книги: еволючія книжкової структури. Львів: Світ. 420 с.

Павлик, М. (1900). Якуб Гаватович (Гават), автор перших руських інтермедій з 1619 р. В «Записки НТШ». Т. ХХХІ. Львів: НТШ. С. 1-44.

Пагутяк, Г. (2006). Слуга з Добромиля. Київ: Видавництво Дуліби. 336 с.

Пагутяк, Г. (2011). Історія в бур'янах, або Як знищили Добромильську друкарню. Відновлено 3: https://zaxid.net/ istoriya_v_buryanah_abo_yak_znishhili_dobromilsku_ drukarnyu_n1229851

Пагутяк, Г. (2011). «Рани в сериі Вітчизни», або За щзо боровся Ян Щасний Гербурт. Відновлено 3: https://zaxid. net/rani_v_sertsi_vitchizni_abo_za_shho_borovsya_yan shhasniy_gerburt_n1129924

Пагутяк, Г. (2013). У̌країнський вірш із XVII століття. Відновлено 3: http://slovoprosvity.org/2013/06/13/ukrains-kyyvirsh-iz-khvii-stolittia/

Пагутяк, Г. (2014). Магнат. Київ: А-БА-БА-ГА-ЛА-МА-ГА. $256 \mathrm{c}$.

Пилипчук, Р. (2019). Історія українського театру (від витоків до кіния XIX cm.). Львів : видавництво ЛНУ ім. Івана Франка. 356 с.

Розмисел про народ руський, написаний під час Московської Конфедерації (1613) паном Щасним Гербуртом Добромильським, старостою Вишницьким та Мостицьким (2008). Перекл. $з$ пол. В. Шевчук. Див.: Украӥна: анто- логія пам'яток державотворення $X-X X \mathrm{~cm}$. Т. 2.: Ренесанс ідеї української державності (XIV-XIVI ст.). Київ: Основи. С. 448-453.

Цебенко, О. (2018). Мистецька спадщина Гербуртів у Галичині XVI - початку XVII століття. Вісник Національної академії мистецтв. 1 (24). С. 381-397.

Cynarski, S. (1960-1961). Herburt Jan Szczęsny h. własnego (1567-1616). W Polski stownik biograficzny, t. IX/3, z. 42. Wrocław : PAN. S. 321-480.

Felsztyn [Фельштин] (1881). W Słownik geograficzny Królestwa Polskiego. Warszawa : Druk «Wieku». T. II. S. 382.

Gałuszka, J. (2017). Uwięziona ambicja. Starania Jana Szczęsnego Herburta o uwolnienie z krakowskiego więzienia po rokiszu Zebrzydowskiego. Studia historyczne. R. LX, z. 3 (239). S. 5-23.

Gawatowicz, J. (1619). Tragaedia, albo Wizerunek śmierci przeświątego Jana Chrzciciela, przestańca Bożego. [Tpazeдія, або Образ смерті пресвятого Яна Хрестителя, послания Божого]. Jaworów. 22 ark.

Kicki, W. (1615). Dialog o obronie Ukrainy y pobudka z przestrog dla zabiezenia incursiom tatarskim. [Діалог про оборону України і побудка з пересторогою для убезпечення від вторгнень татарських]. Dobromil. 26 с.

Łoziński, W. (1904). Prawem i lewem : obyczaje na Czerwonej Rusi w pierwszej połowie XVII.wieku. [Правом і левом : звичаї на Червоній Русі в першій половині ХVII століття] Т. 2. Lwów : H. Altenberg. $560 \mathrm{~s}$.

Serafin, J. (2017). Jan Szczęsny Herburt (1567-1616). Sanok: Muzeum Historyczne. $210 \mathrm{~s}$.

Sokołowski, A. (1883). Jan Szesny Herburt, pierwszy wydawca hroniki Dlugoszowej. Biblioteka Warszawska. T. 2. S. 333-357.

Z dzieów Ukrainy. Księga pamiatkowa. Ku czci Włodzimierza Antonowicza, Paulina Święcickiego, Tadeusza Rylskiego (1912). [3 історії України. Пам’ятна книга. Пам'яті Володимира Антоновича, Павлина Свенціцького, Тадея Рильського]. Kyiów-Kraków : Drukarnia Aleksandra Rippera w Krakowie. 470 s.

\section{References}

Antonovych, D. (1925). Trysta rokiv ukrainskoho teatru 16191919 [Three hundred years of Ukrainian theater 1619-1919]. Praha: Ukrainskyi hromadskyi vydavnychyi fond. 276 s. [in Ukrainian]

Vozniak, M. (1919). Pochatky ukrainskoi komedii (1619-1919) [The beginnings of Ukrainian comedy (1619-1919)]. Lviv: Vydannia «Vsesvitnoi biblioteky». 252 s. [in Ukrainian]

Harbuziuk, M. (2018). Obraz Ukrainy u polskomu teatralnomu dyskursi XIX st.: stratehii ta formy reprezentatsii [The image of Ukraine in the Polish theatrical discourse of the 19th century: strategies and forms of representation]. Lviv: Prostir-M. 470 s. [in Ukrainian]

Huliuk, Ye. (2017). Oberezhno z istoriieiu, abo "drukarski viiny" pid Lvovom [Be careful with history, or «printing wars» near Lviv]. Vidnovleno z: https://photo-lviv.in.ua/oberezhno-z-istorijeyu-abo-drukarski-vijny-pid-lvovom/ [in Ukrainian]

Dziuba, O. M. (2004). Herburt Yan-Shchasnyi. V. A. Smolii (holova) ta in. In: Encyclopedia of the History of Ukraine: $\mathrm{v} 10$ t. T 2: H-D. Kyiv: Naukova Dumka. S. 90. [in Ukrainian]

Dmytrova, L. (1929). Pidruchna knyha $z$ istorii svitovoho teat$r u$ [A textbook on the history of world theater]. (Vstup ta red. O. Biletskyi). Vyp. 1. Kyiv: Derzhavne vydavnytstvo Ukrainy. 472 s. [in Ukrainian]

Zapasko, Ya., Isaievych, Ya. (1981). Pamiatky knyzhkovoho mystetstva: Kataloh starodrukiv, vydanykh na Ukraini [Wonders of book art: Catalog of old prints published in Ukraine]. Kn. 1. Lviv: Vyshcha shkola. S. 37-38. [in Ukrainian]

Isaievych, Ya. (2002). Ukrainske knyhovydannia: vytoky, rozvytok, problemy [Ukrainian book publishing: origins, develop- 
ment, problems]. Lviv: Instytut ukrainoznavstva im. I. Krypiakevycha NAN Ukrainy. 520 s. [in Ukrainian]

Isaievych, Ya. D. (2013). Sheliha, Yan. V V. A. Smolii (holova) ta in. Entsyklopediia istorii Ukrainy [Encyclopedia of the History of Ukraine]. T. 10: T-Ya. Kyiv: Naukova dumka. Vidnovleno z: http://www.history.org.ua/?termin=Sheliha_Y. [in Ukrainian]

Kaminskyi, A.S. (2011). Istoriia Rechi Pospolytoi yak istoriia bahatokh narodiv, 1505-1795. Hromadiany, yikhnia derzhava, suspilstvo, kultura [History of Rzeczpospolita as the History of Many Nations, 1505-1795. Citizens, their state, society, culture]. Perekl. z pol. Kyiv: Nash chas. 263 s. [in Ukrainian]

Kitskyi, V. (2006). Dialoh pro oboronu Ukrainy... Per. z pol. V. Shevchuk. V Slovo mnohotsinne: khrestomatiia ukrainskoi literatury, stvorenoi riznymy movamy v epokhu Renesansu (druha polovyna XV - XVI stolittia) ta v epokhu Baroko (kinets XVI-XVIII stolit)/ [The word is valuable: a textbook of Ukrainian literature created in different languages in the Renaissance (second half of the 15-16 centuries) and in the Baroque era (late 16 - 18 centuries))]: v 4 kn. Kn.1. Kyiv: Akonit. S. 602-620 [in Ukrainian]

Kril, M. (2014). Nyzkyi zamok. V Pamiatky Ukrainy: istoriia ta kultura [Wonders of Ukraine: history and culture]. № 3. S. 20-27 [in Ukrainian]

Lypynskyi, V. (1954). Ukraina na perelomi 1657-1659 : zamitky do istorii ukrainskoho derzhavnoho budivnytstva $v$ XVII-im stolittiu [Ukraine at the turn of 1657-1659: notes on the history of Ukrainian state-building in the 17th century]. Vyd. 2-he. Niu-York: Bulava [in Ukrainian]

Melnyk, I. (2016). Yan Shchasnyi Herburt z Dobromylia [Jan Shchasnyi Herburt from Dobromylia]. Vidnovleno z: https:// zbruc.eu/node/ 60617

Monchak, A. (2020). Nerivna pryiazn. Kliientarni vzaiemyny $v$ istorychnii perspektyvi [Unequal friendship. Client relationships in historical perspective]. Kyiv: Tempora. 768 s. [in Ukrainian]

Onatskyi, Ye. (1967). Ukrainska mala entsyklopediia [Ukrainian small encyclopedia]. Kn. XVI. Litery Ush-Ya. Buenos-Aires : administratura UAPTserkvy. $176 \mathrm{~s}$. [in Ukrainian]

Ovchynnikov, V. (2005). Istoriia knyhy: evoliutsiia knyzhkovoi struktury [History of the book: the evolution of the book structure]. Lviv: Svit. $420 \mathrm{~s}$.

Pavlyk, M. (1900). Yakub Gavatovych (Gavat), avtor pershykh ruskykh intermedii z 1619 r. [Yakub Gavatovych (Gavat), the author of the first Russian interludes from 1619]. V «Zapysky NTSh». T. XXXI. Lviv: NTSh. S. 1-44 [in Ukrainian]

Pahutiak, H. (2006). Sluha z Dobromylia [Servant from Dobromyl]. Kyiv: Vydavnytstvo Duliby. 336 s. [in Ukrainian]

Pahutiak, H. (2011). Istoriia v burianakh, abo yak znyshchyly Dobromylsku drukarniu [History in the weeds, or how the Dobromyl printing house was destroyed] Vidnovleno z: https:// zaxid.net/istoriya_v_buryanah_abo_yak_znishhili_dobromilsku_drukarnyu_n1229851 [in Ukrainian]

Pahutiak, H. (2011). "Rany v sertsi Vitchyzny», abo Za shcho borovsia Yan Shchasnyi Herburt. [ «Wounds in the heart of the Fatherland», or What Jan Szczasny Herburt fought for].
Vidnovleno z: https://zaxid.net/rani_v_sertsi_vitchizni_abo za_shho_borovsya_yan_shhasniy_gerburt_n $\overline{11} 29924$ [in Ukrainian]

Pahutiak, H. (2013). Ukrainskyi virsh iz XVII stolittia [Ukrainian poem from the seventeenth century]. Vidnovleno z: http:// slovoprosvity.org/2013/06/13/ukrains-kyy-virsh-iz-khviistolittia/ [in Ukrainian]

Pahutiak, H. (2014). Mahnat [Magnate]. Kyiv: A-BA-BA-HALA-MA-HA. $256 \mathrm{~s}$. [in Ukrainian]

Pylypchuk, R. (2019). Istoriia ukrainskoho teatru (vid vytokiv do kintsia XIX st.) [History of Ukrainian theater (from the origins to the end of the 19th century)]. Lviv: vydavnytstvo LNU im. Ivana Franka. 356 s. [in Ukrainian]

Shevchuk, V. [Transl.]. (2008). Rozmysel pro narod ruskyi, napysanyi pid chas Moskovskoi Konfederatsii (1613) panom Shchasnym Herburtom Dobromylskym, starostoiu Vyshnytskym ta Mostytskym. [A reflection on the Rus people, written during the Moscow Confederation (1613) by Mr. Szczasny Herburt Dobromylsky, the head of Vyshnytsia and Mostyska (2008).] Perekl. z pol. V. Shevchuk. V Ukraina: antolohiia pamiatok derzhavotvorennia $X-X X$ st. [Ukraine: an anthology of important moments of state formation of the XXX centuries]. T. 2. Renesans idei ukrainskoi derzhavnosti (XIV-XIVI st.). Kyiv: Osnovy. S. 448-453 [in Ukrainian]

Tsebenko, O. (2018). ). Mystetska spadshchyna Herburtiv u Halychyni XVI - pochatku XVII stolittia [The artistic heritage of the Herburts in Galicia in the 16th - early 17th centuries]. Visnyk Natsionalnoi akademii mystetstv. 1 (24). S. 381-397 [in Ukrainian]

Cynarski, S. (1960-1961). Herburt Jan Szczęsny h. własnego (1567-1616). W Polski stownik biograficzny, t. IX/3, z. 42. Wrocław : PAN. S. 321-480 [in Poland]

Felsztyn [Фельштин] (1881). W Stownik geograficzny Królestwa Polskiego. Warszawa : Druk «Wieku». T. II. 382 s. [in Poland]

Gałuszka, J. (2017). Uwięziona ambicja. Starania Jana Szczęsnego Herburta o uwolnienie z krakowskiego więzienia po rokiszu Zebrzydowskiego. Studia historyczne. R. LX, z. 3 (239). S. 5-23 [in Poland]

Gawatowicz, J. (1619). Tragaedia, albo Wizerunk śmierci przeświatego Jana Chrzciciela, przesłańca Bożego. Jaworów. 22 ark. [in Poland]

Kicki, W. (1615). Dialog o obronie Ukrainy y pobudka z przestrog dla zabiezenia incursiom tatarskim. Dobromil. $26 \mathrm{~s}$. [in Poland]

Łoziński, W. (1904). Prawem i lewem : obyczaje na Czerwonej Rusi w pierwszej połowie XVII.wieku. T. 2. Lwów : H. Altenberg. 560 s. [in Poland]

Serafin, J. (2017). Jan Szczęsny Herburt (1567-1616). Sanok: Muzeum Historyczne. 210 s. [in Poland]

Sokołowski, A. (1883). Jan Szesny Herburt, pierwszy wydawca hroniki Dlugoszowej. Biblioteka Warszawska. T.2. S. 333357 [in Poland]

Z dzieów Ukrainy. Księga pamiątkowa. Ku czci Włodzimierza Antonowicza, Paulina Święcickiego, Tadeusza Rylskiego (1912). Kyiów-Kraków : Drukarnia Aleksandra Rippera w Krakowie. 470 s. [in Poland]

\section{Maiia Harbuziuk
«Tragedy, or The Image of the Death of St. John the Baptist» by J. Gavatovych as a Document of the Polish-Ukrainian Theatrical Border: Sketches to the History

Abstract. The article is devoted to the widening of non-theatrical contexts of the performance «Tragedy, or the Image of the Death of St. John the Baptist ...» by J. Gavatovych (1619). For the first time, the author indicates a possible connection between the history of life and public activity in defense of Ruthenians (Ukrainians) of the Polish figure Jan Szczasny Herburt (1567-1616), and the fate of his Dobromyl printing 
house. Besides, the author indicates the possible connection to the fact of appearance of a bilingual «Tragedy...» by J. Gavatovych and the assistance of Regina Zholkevska from Herburt family. It is hypothesized that the printing of the «Tragedy...» could be a way of symbolic, covert commemoration of Jan Szczasny Herburt, or at least it became an integral part of the Polish-Ukrainian cultural dialogue of early modern times.

Keywords: Polish-Ukrainian theatrical border, Herburt, Zholkiewski, Jan Szczasny Herburt, Dobromyl printing house.

\section{Гарбузюк Майя Владимировна}

\section{«Трагедия, или Образ смерти...» Я. Гаватовича как документ польско-украинского пограничья: предпосылки к истории}

Аннотация. Статья посвящена расширению внетеатральных контекстов постановки «Трагедия, или Образ смерти пресвятого Иоанна Крестителя...» Я. Гаватовича (1619). Впервые акцент поставлен на возможной связи истории жизни и общественной деятельности в защиту русинов (украинцев) польского деятеля Яна Щасного Гербурта (1567-1616) и его Добромильской типографии с фактом посмертного появления в ней двуязычной «Трагедии...» Я. Гаватовича при содействии Регины Жолкевской из Гербуртов. Предложена гипотеза о том, что издание «Трагедии...» могло быть способом символической, потаённой дани памяти Яна Щасного Гербурта или же, по крайней мере, стало неотъемлемой частью польско-украинского культурного диалога раннемодерного периода Речи Посполитой.

Ключевые слова: польско-украинское театральное пограничье, Гербурты, Жолкевские, Ян Щасный Гербурт, Добромильская типография. 